\title{
A Review on Automated Billing for Smart Shopping System Using IOT
}

\author{
Priyanka S. Sahare ${ }^{1,2^{*}}$, Anup Gade ${ }^{2}$, Jayant Rohankar ${ }^{2}$ \\ ${ }^{1}$ P.G. Scholar, Department of Information \& Technology, RTMNU University, Nagpur, Maharashtra 440033, India \\ ${ }^{2}$ Tulsiramji Gaikwad Patil College of Engineering Technology, Nagpur, Maharashtra 441108, India
}

Corresponding Author Email: priyanka.sahare02@gmail.com

https://doi.org/10.18280/rces.060101

Received: 20 December 2018

Accepted: 16 February 2019

\section{Keywords:}

RFID 1, smart shopping 2, raspberry-pi 3, smart trolley 4

\begin{abstract}
A shopping mall is a form where wide variety of product items is available. This product can be clothes, beverages, books or food any domestic product. The main intention of supermarkets is to provide availability of all the items and save the time of the purchaser but sometimes purchaser gets discontented while waiting in the queue at cash counter and sometimes they get frustrated while balancing the total price of all the products with the budget in the pocket before billing. To swamp these problems, Shopping malls use this technique as a strategy to increase the number of purchasers. In big cities, we can observe an enormous flash at shopping malls on weekends. This becomes even more when there is diversity of offers and discount. Now a day's people buy a variety of items and put them in the trolley. After total buying one should approach counter for billing purpose. By using reader the paymaster prepares the bill which is a tedious process. This results in long queues at the cash counters. This project presents an idea to develop a system in shopping malls to conquer the above problem. When purchaser puts any item in the trolley its details will be recognized automatically, the item name and rate will be displayed on the LCD Screen, thereby the rate gets joined to the final bill. If a purchaser wishes to extract the items from the smart trolley, purchaser can take away the product and the price of that particular item gets subtracted from total amount and the same information passes to the central billing unit via GSM module.
\end{abstract}

\section{INTRODUCTION}

For instance, the expertise is up-and-coming and seeing different developments in several fields counting machine learning, AI, and internet of things Raspberry Pi. The carts in the superstores or shopping mall are resolutions so as to automatically bill the items put into them and the final bill is sent to a web application which can be accessed in any mobile phone [1]. The system is also giving it to anti-theft controlling where the system doesn't let any consumer take non-billed items. The word smart is trending lately in the field of IOT [2]. Every object around us is being made smart so as to make our work easier. With the increase in internet technology, food items are available at our door steps whenever needed. The benefit is that we can prudently select the best product according to our choice. The major disadvantage of this is standing in overextended out line of consumers for paying off the bill. The carried forward smart shopping structure avoids this disadvantage and also has extra features for the suitability of the consumer [3]. The exaggerated Shopping trolley System assistances the consumers in reducing the substantial amount of time those consumers used to expend in shopping. In this shopping trolley system, real-time informs on the records are also provided in the store management unit. The main technologies that play a vigorous role in this proposed system are:

(i) Raspberry Pi for achieving wireless communication with Server

(ii) Web application displaying total to be paid and supervision the inventories factor. (iii) RFID tags for item identification details.

\section{LITERATURE SURVEY}

\subsection{Smart shopping cart}

In [4] this paper the author designed system for shopping mall. The system is placed in the trolleys. It consists of RFID reader and each product has RFID tag. The billing is done in smart trolley itself. Product name and its price display on LCD screen. At the cash counter the total bill relocated to Personal Computer by wireless Radio Frequency module. The disadvantage of this scheme is after completion of shopping, a key is pressed indicating the final promoting amount of the entire item, and we can't add or remove the products.

\subsection{Innovative shopping cart}

In [5] this paper the author designed system for shopping mall. In this paper they developed a smart way for shopping. In every item has RFID tag in its place of barcode scanner. The smart trolley involves of RFID reader LCD screen and Zigbee transmitter. The sum total cost of all the products will be added to the final bill, which will be kept in the microcontroller memory. Drawback of the system is in Zigbee there is distance barrier is occurred. 


\subsection{Smart trolley using Arduino}

In [6], this paper the author invented such a system it consists of RFID, ARM7, Display, Power supply, Switch, IR sensor pair, Barcode reader Visual Basics. The system works as the inventor use the barcode reader as well as RFID. And our shopping is done through the serial communication we transferred the total bill to the counter for printing the hardcopy of the product bill. There is also facility for the payment is credit card or any other. The drawback of the system is their uses both the reader RFID and Barcode Reader because of that the system becomes more multifaceted.

\subsection{RFID based advanced shopping trolley for super market}

In this paper the author found such a system it consists of GSM, RFID, Automatic Billing, OTP, ZIGBEE, PIC. In this scheme, the item can be read by the reader and the total of the item is showed on the LCD screen [7].

They characterized this paper because they added some additional features in existing system like in this system the product weight and name shown on display; if item weight is less than stored weight then buzzer will beep.

\subsection{Smart trolley with smart billing}

In [8] this paper the author invented such a system that present the paper smart trolley with smart billing. In that they are representing the system with additional functionality which will calculate and update the customer bill when they store the purchased product.

Also when shopping is done the customer have to press a key then the billing counter display the number of particular trolley on LCD screen and then consumer have to go and do the billing at the counter. The new bill is generated only if the customer detached some creation from their shopping [9].

Drawbacks: -It is difficult to stick RFID tag to some products [10]. Here ZIGBEE is used to launch the communication between trolley and billing counter so the ZIGBEE is having a distance barrier.

\subsection{Human guided smart trolley}

Using Arduino and RFID, a Human Guided Trolley with Smart System was developed. This paper presents the hardware and software devise of the moveable machine.

\subsection{RFID-Cloud smart cart system}

Using RFID expertise for billing of the purchased item includes especially deliberate $\mathrm{PCB}$, a $\mathrm{Wi}-\mathrm{Fi}$, and a power supply to intend the shopping cart [11].

Smart trolley is estimated that it will be capable of generating a bill from the trolley itself provides centralized and automatic billing system.

\section{CHALLENGES OF PRESENT SYSTEM}

- It takes too much of time to scan details of each item.

- Consumers used to estimate total sum to be paid manually to fix in modest.

- Consumers have to wait in a long row for the transaction purpose.

- Barcode scanners need a direct line of vision to the barcode to be capable to read.

- In command to read the barcode, the barcode scanner needs to be rather near; about no more than $10 \mathrm{ft}$.

- Barcodes have not at all any read/write competences; they don't consist of any extra particulars for instance running out date etc.

- In the present system, bar codes are used are for skimming the item information where the consumers be likely to wait in long row for producing the bill monitored by expenditure.

- Every single item has to be perused physically.

Table 1. Literature review analysis

\begin{tabular}{|c|c|c|c|c|}
\hline SNO & PAPER TITLE & YEAR & AUTHORS & ANALYSIS \\
\hline 1 & Smart shopping cart & 2017 & $\begin{array}{l}\text { 1. Akshay Kumar } \\
\text { 2. S Balamurugan } \\
\text { 3. S Balaji } \\
\text { 4. Marimuthu R }\end{array}$ & $\begin{array}{l}\text { This project mainly focused on autonomous technology to scan the } \\
\text { products and store it in mobile database and Payment is through } \\
\text { mobile banking. }\end{array}$ \\
\hline 2 & $\begin{array}{l}\text { Innovative Shopping } \\
\text { Cart }\end{array}$ & 2017 & $\begin{array}{l}\text { 1. Prasiddhi K. } \\
\text { 2. Dhansashri } \\
\text { H.Gawali }\end{array}$ & $\begin{array}{l}\text { Using RFID and zigBee technology, an inexpensive RFID tag can be } \\
\text { attached to each product and scan it with RFID reader. }\end{array}$ \\
\hline 3 & $\begin{array}{l}\text { RFID based Advanced } \\
\text { Shopping Trolley for } \\
\text { Super Market }\end{array}$ & 2017 & $\begin{array}{l}\text { 1.Manikandan } \\
\text { Thiyagarajan, } \\
\text { 2. Mohammed Aejaz } \\
\text { 3. Nithin Krishna } \\
\text { 4. Mohan Kumar }\end{array}$ & $\begin{array}{l}\text { Using RFID technology, RFID reader present in each trolley and } \\
\text { RFID tag for each item, reader scans each product rate and brand of } \\
\text { the product and the information will be shown on the LCD screen. }\end{array}$ \\
\hline 4. & $\begin{array}{l}\text { Smart trolley using } \\
\text { Smart Phone and } \\
\text { Arduino }\end{array}$ & 2017 & $\begin{array}{l}\text { 1. HarpeetBedi } \\
\text { 2. Kumar S } \\
\text { 3. Gupta A }\end{array}$ & $\begin{array}{l}\text { This application uses RFID to scan the products and sends the details } \\
\text { to database. Shopping commences by pressing start button and ends } \\
\text { by pressing stop button provided in the trolley }\end{array}$ \\
\hline 5. & Smart Trolley & 2016 & $\begin{array}{l}\text { 1. Sarmad Ali } \\
\text { 2. MahreenRiaz } \\
\text { 3. Hugo Fernando } \\
\text { 4. Mingzhi Sun } \\
\text { 5. Ibanda Tex Tembi }\end{array}$ & $\begin{array}{l}\text { In this application consumer can self-scan the barcodes using } \\
\text { ultrasonic sensor that is attached to the trolley } \\
\text { Items in the trolley with a purchaser ID is linked with supermarket } \\
\text { backend database which contains features of the goods such as cost } \\
\text { price and other details. }\end{array}$ \\
\hline
\end{tabular}




\begin{tabular}{|c|c|c|c|c|}
\hline 6 & $\begin{array}{l}\text { RFID-Cloud smart cart } \\
\text { system }\end{array}$ & 2016 & $\begin{array}{l}\text { 1. YerlanBerdaliyev } \\
\text { 2. AlexPappachen } \\
\text { James }\end{array}$ & $\begin{array}{l}\text { Using RFID technology for billing of the purchased item includes } \\
\text { particularly calculated PCB, a Wi-Fi, and a power supply to intend the } \\
\text { shopping trolley. }\end{array}$ \\
\hline 7 & $\begin{array}{l}\text { An IOT Based Smart } \\
\text { Shopping Cart for Smart } \\
\text { Shopping }\end{array}$ & 2018 & $\begin{array}{l}\text { 1. Srinidhi Karjol } \\
\text { 2. Anusha K. Holla } \\
\text { 3. C. B. Abhilash }\end{array}$ & $\begin{array}{l}\text { This project provides trolley to trolley communication that helps the } \\
\text { consumers to shop with friends and family. }\end{array}$ \\
\hline 8 & $\begin{array}{l}\text { Smart Cart with } \\
\text { Automatic Billing }\end{array}$ & 2016 & $\begin{array}{l}\text { 1. Ankush } \\
\text { Yewatkara } \\
\text { 2. Faiz Inamdarb } \\
\text { 3. Raj Singh } \\
\text { 4. Ayushyad } \\
\text { 5. Amol Bandale } \\
\end{array}$ & $\begin{array}{l}\text { This application provides anti- theft controlling system for a } \\
\text { superstore. It will allow online transaction process for billing, and it } \\
\text { will also give suggestions to the customer for purchasing items. }\end{array}$ \\
\hline 9 & $\begin{array}{c}\text { Smart Trolley System } \\
\text { For } \\
\text { Automated Billing Using } \\
\text { RFID And Zigbee } \\
\end{array}$ & 2016 & $\begin{array}{l}\text { 1. P.Chandrasekar } \\
\text { 2. T.Sangeetha }\end{array}$ & $\begin{array}{l}\text { The smart trolleys consist of RFID reader LCD display and Zigbee } \\
\text { transmitter. }\end{array}$ \\
\hline
\end{tabular}

\section{PROPOSED METHDOLOGY}

The key objective of future system is to deliver an expertise concerned with, low-cost, easily accessible, and an even System for supporting shopping. The RFID power-driven electronic shopping trolley is built to improve the complete shopping understanding for computer electronics store consumers. Upon enlisting a thing in the shopping trolley, the consumers can admittance variety of item information.

A customer goes into a shopping centre then she/he first takes a trolley. Every last trolley is joined with a RFID reader per user. The context work is the idea at which the purchaser buys a thing, the purchaser must be inspecting the thing first with help of identical tag are available in each item using the RFID per consumer. At that point that attained thing can be fixed into the cart. While the customer is inspecting the RF tag of the item, a cost of the buying item is taken and secure in the framework's memory. When the customer punch RFID card to RFID reader, RFID reader will give identical number of RFID card to Raspberry pi via serial communication. Raspberry pi will get the details of ID from the database, to show on LCD. LCD will show recent product details along with the total cart amount. It will help the customer to not to cross the budget limit. As soon as we press the key placed on it, it will send the data to billing counter automatically.

The block diagram is as follows:

Figure 1. Block diagraom of setup

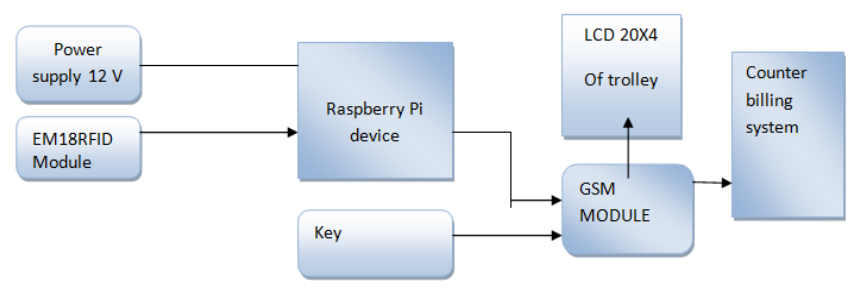

\section{ADVANTAGES OF PROPOSED SYSTEM OVER EXISTING SYSTEM}

Table 2. Comparison of proposed system with existing system

\begin{tabular}{|c|c|}
\hline Existing System & Proposed System \\
\hline Manual billing & Automatic billing \\
\hline Using Bar code for billing & Using RFID for billing \\
\hline $\begin{array}{c}\text { Human supervise needed for } \\
\text { billing }\end{array}$ & $\begin{array}{c}\text { Human supervise not needed } \\
\text { for billing }\end{array}$ \\
\hline
\end{tabular}

\begin{tabular}{|c|c|}
\hline $\begin{array}{c}\text { Getting item details is } \\
\text { problematic and time } \\
\text { overwhelming. }\end{array}$ & $\begin{array}{c}\text { Getting item details is } \\
\text { informal and no additional } \\
\text { time needed. }\end{array}$ \\
\hline $\begin{array}{c}\text { Low item cost but overall } \\
\text { expenditures are much high. }\end{array}$ & $\begin{array}{c}\text { Item is little expensive but } \\
\text { overall expenditures is much } \\
\text { low. }\end{array}$ \\
\hline $\begin{array}{c}\text { It does not reveal any } \\
\text { automatic way of indicating to } \\
\text { customer how the total bill is. }\end{array}$ & $\begin{array}{c}\text { LCD is present which will } \\
\text { display the updated bill every } \\
\text { time item is added. }\end{array}$ \\
\hline
\end{tabular}

Table 3. Comparison between RFID and barcode

\begin{tabular}{|c|c|c|}
\hline Specification & RFID & BARCODE \\
\hline Read Process & Radio signals & Optical scanner \\
\hline Line of Sign & Not necessary & Necessary \\
\hline Read Range & $0-50$ feet & $0-12$ inches \\
\hline Read Ratio & Many at once & One at a time \\
\hline Tag Stability & $\begin{array}{c}\text { Can be very long- } \\
\text { lasting }\end{array}$ & $\begin{array}{c}\text { Not usually long- } \\
\text { lasting }\end{array}$ \\
\hline Price & $\begin{array}{c}\text { Typically more } \\
\text { costly than barcode }\end{array}$ & $\begin{array}{c}\text { Typically less } \\
\text { costly than RFID }\end{array}$ \\
\hline
\end{tabular}

\section{ALGORITHM}

- Start the procedure.

- Initialize the system

- Scan a product in RFID tags.

- Check the RFID tags.

- If the tag is registered or scanned, RFID reader can read the information from memory.

- Display the data and cost with help of LCD.

- The item is added automatically and total cost will be calculated and displayed on LCD.

- If any item is removed, the total cost is deducted by the particular removed item and again the process will be continuing.

- On pressing send key, the total amount will reflect on billing system.

- Bill will be generated.

- And text message will be sent to user.

- The process is end.

\section{REQUIREMENTS}

- Raspbeanlite

- PROGRAMMING LANGUAGE 
- Python programming language will be used for Raspberry pi.

- Html Language

- Php Language

- DATABASE

\section{- SQLITE}

- XAMPP SERVER

- XAMPP provides support for creating and manipulating databases in SQ-Lite.

- HARDWARE REQUIREMENTS

$\begin{array}{ll}\circ & \text { RFID Tag } \\ \circ & \text { RFID Reader } \\ \circ & \text { LCD Display } \\ \circ & \text { Raspberry Pi Device }\end{array}$

\section{FLOWCHART OF PROPOSED SYSTEM}

Table 4. Flowchart

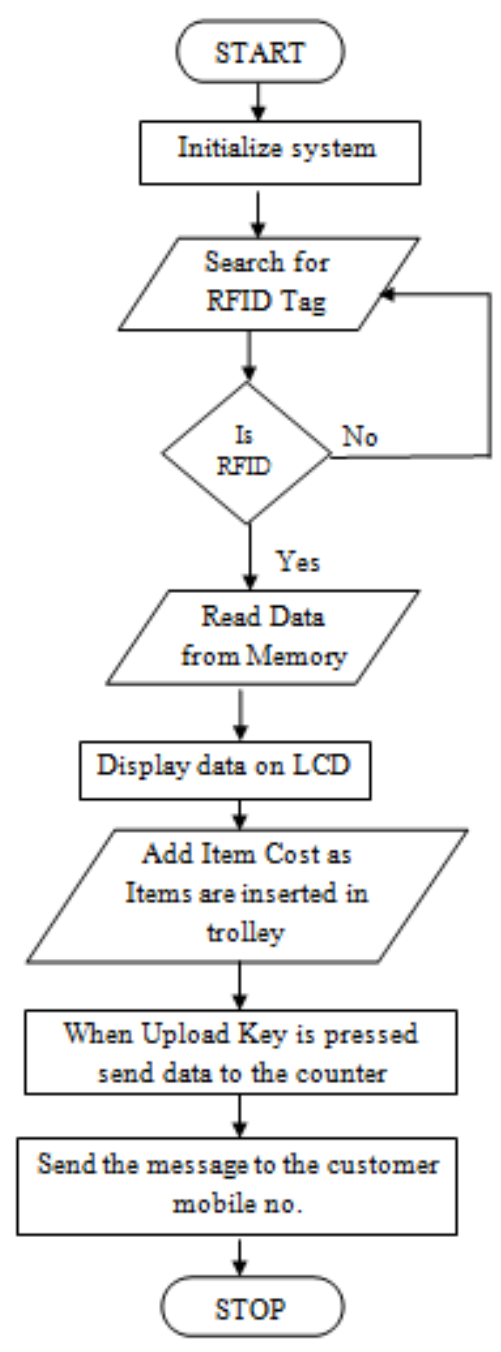

\section{COMPONENTS USED IN THE PROJECT}

\section{RFID READER}

RFID reader is use to interpret the data there in the RFID tag. RFID readers are self-possessed of a RF module, a control unit and a transmitter to cross-examine electronic tag via radio frequency (RF) communication.

\section{LCD DISPLAY}

Displays the item name, rate, end date and total amount.

- Complete listings of the items along with their rate on LCD display.

- Up/down switch are interfaced with the microcontroller which can be used to analysis all the purchase.

\section{RASPBERRY PI DEVICE}

The device has involved through a number of versions that facet variations in capability and peripheral-tool support.

\section{GSM MODULE}

The GSM /SMS element further supervise that you're PC and your application runs properly.

\section{CONCLUSION}

This article reviewed different papers on smart shopping systems, from the above literature it can be stated that shopping can be made easier by using smart trolley and such systems will be able to build by using different controllers. At the same time using these controllers may take the system in bulky mode which can be further area of research. To overcome this problem, we can use the Raspberry pi to implement smarter system. By using raspberry pi, the system size would be approachable or convincing, easy to interface and there is no need of extra module to interface the RFID \&other components. The execution part will be done in Python because of effective performance with limited length and easy to understand.

\section{REFERENCES}

[1] Machike K, Golait M, Rathod R, Petkar R, Goche P. (2017). A new technology of smart trolley using RFID and ZIGBEE. International Journal on Recent and Innovation Trends in Computing and Communication 5(2): 256-259.

[2] Thiyagarajan M, Aejaz M, Kumar M. (2017). RFID based advanced trolley for super market. Special Issue 8 .

[3] Prasad JS, Kumar BOP, Roopa D, Arjun AK. (2011). A novel low-cost intelligent shopping cart. IEEE 2nd International Conference on Networked Embedded Systems for Enterprise Applications, pp. 1-4.

[4] Karpagam V, Balapriya S, Kalairubini G, Kalaivani A. (2017). Smart trolley with smart billing. |International Journal of Computer Systems 4(3): 55-58.

[5] Gade A, Bhatt N, Thakare N. (2018). Survey on energy efficient cloud: A novel approach towards green computing. Helix 5(5): 3976-3979. https://doi.org/10.29042/2018-3976-3979

[6] Chandrasekar P, Sangeetha T. (2014). Smart shopping cart with automatic billing system through RFID and Zigbee. Information Communication and Embedded Systems (ICICES 2014), pp. 1-4. https://doi.org/10.1109/ICICES.2014.7033996

[7] Ms. Rupali Sawant, Kripa Krishnan, Shweta Bhokre, Priyanka Bhosale (2015). The RFID based smart shopping cart. International Journal of Engineering 
Research and General Science 3(2): 275-280.

[8] Dawkhar K, Dhomase S, Mahabaleshwarkar S. (2015). Electronic shopping cart for effective shopping based on RFID. International Journal of Innovative Research in Electrical, Electronic, Instrumentation and Control Engineering 3(1): 84-86. https://doi.org/10.17148/IJIREEICE.2015.3117

[9] Ambekar K, Dhole V, Sharma S, Wadekar T. (2015). Smart shopping trolley using RFID. International Journal of Advanced Research in Computer Engineering \& Technology (IJARCET) 4(10): 3875-3877.

[10] Shelke CJ, Karde P, Thakre VM. (2015). Study of various perspectives of android security. International Journal of Innovative Research in Computer and Communication Engineering 3(10): 9667-9672. https://doi.org/10.15680/IJIRCCE.2015. 0310116

[11] Balaji S, Balamuruguan S, Marimuthu R. (2017). Smart shopping cart. IEEE Internet of Things Journal.

[12] Bedi H, Goyal N, Kumar S, Gupta A. (2017). Smart trolley using Smart phone and Arduino. Journal of Electrical \& Electronic Systems 2(12): 6. https://doi.org/10.4172/2332-0796.1000223

[13] Thiyagarajan M, Aejaz M, Kumar M. (2017). RFID based advanced shopping trolley for super market. Research Gate Journal 8.

[14] Berdaliyev Y, James AP. (2016). Smart shopping cart using Zigbee department of electrical and electronic engineering school of engineering. Nazarbayev University Astana, Kazakhstan.

[15] Saad SS, Nakad ZS. (2011). A standalone RFID indoor positioning system using passive tags. IEEE Transactions on Industrial Electronics 58(5): 1961-1970. https://doi.org/10.1109/TIE.2010.2055774

[16] Chandra Babu DVS. (2012). Wireless intelligent billing trolley for supermarket. International Journal of Advanced Research in Technology 3(1).

[17] Yewatkara A, Inamdarb F, Singh R, Bandale AA. (2018). Smart billing trolley via application. International Journal of Advance Research in Engineering, Science \& Technology 5(3).

[18] Larsan Aro Brian A, Arockiam L, Sheba Kezia Malarchelvi PD. (2014). An IOT based secured smart library system with NFC based book tracking. International Journal of Emerging Technology in Computer Science \& Electronics (IJETCSE) 11(5): 1821. 